\title{
Effect of the copepod parasite Nicothoë astaci on haemolymph chemistry of the European lobster Homarus gammarus
}

\author{
Charlotte E. Davies ${ }^{1, *}$, Claire L. Vogan ${ }^{2}$, Andrew F. Rowley ${ }^{1}$ \\ ${ }^{1}$ Department of Biosciences, College of Science, and ${ }^{2}$ College of Medicine, Swansea University, Swansea, SA2 8PP, UK
}

\begin{abstract}
The gills of the European lobster Homarus gammarus (L.) are susceptible to parasitization by the copepod Nicothoë astaci, the lobster louse. This copepod feeds on haemolymph of the host and can damage the gills, potentially affecting gaseous exchange capabilities. To investigate the host response to the parasite, haemolymph levels of total protein, haemocyanin, glucose and ammonia were quantified in adult lobsters carrying varying parasite loads. Parasite loads correlated positively with total haemolymph protein and haemocyanin concentrations but not with glucose or ammonia concentrations. The data suggest that lobsters with gills damaged by the feeding activities of $N$. astaci respond by producing higher levels of haemocyanin, which is both a key defence response and may compensate for their decreased respiratory functioning.
\end{abstract}

KEY WORDS: Lobster louse · Haemolymph proteins · Haemocyanin - Glucose · Ammonia · Ectoparasites $\cdot$ Blood chemistry

\section{INTRODUCTION}

The lobster louse Nicothoë astaci is a copepod ectoparasite that inhabits the gills of some European lobsters Homarus gammarus and was first reported in 1826 by Audoin \& Milne-Edwards (see Jones 1861). $N$. astaci has been found on lobsters inhabiting locations including Scotland (Mason 1959), Lundy Island in the Bristol Channel (Wootton et al. 2011) and as far south as France (M. Laurans pers. comm.) and Portugal (Monteiro 2008). The louse possesses a narrow suctorial mouthpart to feed on host haemolymph (Wootton et al. 2011, Davies et al. 2014). Internally, lobsters respond to the parasite by encapsulating haemocytes in an attempt to partition off damaged gill areas, and Wootton et al. (2011) hypothesized that this response may impair gill respiratory function. Such impaired respiratory function may explain why high louse loads have been associated circum- stantially with elevated mortality among lobsters in holding facilities (M. Laurans pers. comm.).

Various haemolymph factors can provide a general health indicator of crustaceans (Stewart et al. 1967). For example, haemolymph levels of hyperglycaemic hormone and heat-shock proteins increase in response to environmental stressors such as temperature, salinity and hypoxia (Chang 2005), as well as to physiological stressors such as moulting (Stewart \& Li 1969, Chang 2005). In response to reduced oxygen availability due to compromised gill functioning or removal from water, reduced oxygen concentrations in haemolymph can trigger increases in haemocyanin levels (Taylor \& Whiteley 1989, Burnett 1992, Brouwer et al. 2004) to bolster the oxygen transport capability of haemolymph (Depledge \& Bjerregaard 1989). Levels of digestion products such as glucose and nitrogenous wastes (Claybrook 1983, Truchot 1983) can also be affected by moult stage and exoge- 
nous stressors such as temperature, handling, disease and parasitization (Spindler-Barth 1976, Santos \& Keller 1993, Stentiford et al. 2001). Moreover, crustaceans excrete nitrogen produced from protein catabolism across their gills, primarily as ammonia. Haemolymph levels of ammonia can also change in response to stress (Hunter \& Uglow 1993) and can fall, for example, when stressors such as handling or low salinity promote elevated gill excretion (Regnault 1987).

Reduced respiratory function could have implications for lobsters parasitized with $N$. astaci, particularly when exposed to the stress of capture and live storage. Crustacean gills undertake many physiological functions including ion transport needed for haemolymph osmoregulation and ammonia excretion. They also provide a large surface area and a thin epithelium diffusion distance (ca. 1-10 $\mu \mathrm{m}$ ) to exchange gases efficiently (Taylor \& Taylor 1992, Hsia et al. 2013). However, their delicate nature also makes them vulnerable to damage from both waterborne debris and pathogens, including parasites. Here, we investigated the impact of $N$. astaci abundance on $H$. gammarus haemolymph levels of glucose, ammonia and proteins including haemocyanin.

\section{MATERIALS AND METHODS}

\section{Lobster collection and maintenance}

European lobsters $(\mathrm{n}=18$; 3 males and 15 females; carapace length \pm SD $96.1 \pm 3.5 \mathrm{~mm}$; weight $581.4 \pm$ $74.4 \mathrm{~g})$ above the legal minimum landing size ( $\geq 90 \mathrm{~mm}$ carapace length measured from eye socket to posterior end of carapace) were collected from a commercial fishing vessel. Lobsters were caught at Ilfracombe, Devon, UK, where parasitization by Nicothoë astaci has been found previously (Wootton et al. 2011). An endoscope (Pro Vision PV2-2in1) was used to verify the presence of parasites in lobster gills, and the 18 lobsters examined were selected at random across 9 potting locations. It was not possible to quantify parasite loads accurately by endoscope examination. After transport in iced seawater to Swansea University (6 h duration), lobsters were acclimated for $2 \mathrm{wk}$ to aid recovery from handling and transportation stress. Lobsters were maintained across 3 aquarium tanks (6 lobsters tank ${ }^{-1}$ ) employing recirculated sea water $\left(\mathrm{pH} 7.9-8.1,18-21^{\circ} \mathrm{C}\right.$, dissolved oxygen 6-8 $\mathrm{mg} \mathrm{l}^{-1}$, as recorded before each sampling) and fed a diet of mussels Mytilus edulis 3 times $\mathrm{wk}^{-1}$.

\section{Haemolymph and gill sampling}

Each week over a 4 wk sampling period, haemolymph (1 ml) was withdrawn from the haemal sinus at the base of the fifth pereiopod (walking leg) using a 21-gauge needle. It was left to clot on ice for ca. $2 \mathrm{~h}$ and then centrifuged $(5000 \times g, 5 \mathrm{~min})$, and $200 \mu$ aliquots of supernatant (serum) were stored at $-80^{\circ} \mathrm{C}$. Unless otherwise stated, all assays were performed in triplicate using flat-bottom 96-well microtitre plates with absorbance measured using a Tecan Sunrise Basic microplate reader. On Days 28 or 29,1 to $2 \mathrm{ml}$ of $149 \mathrm{mg} \mathrm{ml}^{-1} \mathrm{KCl}$ was injected into the cardiac sinus to euthanize each lobster (Battison et al. 2000). Gills were excised according to Wootton et al. (2011), and parasites were counted and recorded photographically.

\section{Protein quantification}

Serum total protein concentration was determined using a bicinchoninic acid assay kit (ThermoFisher), according to the manufacturer's instructions. Briefly, defrosted serum was diluted 100-fold in marine saline (16 g NaCl, 0.88g CaCl $2 \cdot 2 \mathrm{H}_{2} \mathrm{O}, 0.41 \mathrm{~g} \mathrm{KCl}, 1.24 \mathrm{~g}$ $\mathrm{MgCl}_{2}, 2.98 \mathrm{~g} \mathrm{HEPES}$, ddH $\mathrm{O}_{2} 500 \mathrm{ml}$ ) and following addition of kit reagents, absorbance at $505 \mathrm{~nm}\left(A_{505}\right)$ was measured. Protein levels were quantified relative to a dilution series of bovine serum albumin standards (100-1000 $\mathrm{g} \mathrm{m} \mathrm{ml}^{-1}$ ) analysed in the same 96-well plate.

\section{Haemocyanin quantification}

Using a method to quantify haemocyanin adapted from Hagerman (1983), $100 \mu$ of defrosted serum were diluted 1:10 to $1 \mathrm{ml}$ with marine saline and $A_{335}$ measured in triplicate in $10 \mathrm{~mm}$ quartz-microcuvettes using a Jenway 6315 spectrophotometer. Since haemocyanin is oxygenated rapidly in vitro, this is an effective measure of pigment concentration using an extinction coefficient $\mathrm{E}^{\mathrm{mM}}{ }_{1 \mathrm{~cm}}=17.26$. This value was calculated from $E^{1 \%}{ }_{1 \mathrm{~cm}}=2.83$ on the basis of a minimal functional unit size of $74 \mathrm{kDa}$ (Nickerson \& Van Holde 1971, Antonini \& Brunori 1974).

\section{Glucose quantification}

Glucose concentrations in serum were quantified using a Glucose (GO) Assay Kit (Sigma Chemical) with slightly modified manufacturer's instructions. 
Briefly, defrosted serum was de-proteinised with an equal volume of $5 \%$ trichloro-acetic acid and, following the addition of kit reagents, $A_{540}$ was measured. The glucose levels were quantified relative to a dilution series of glucose standards $\left(920-1000 \mu \mathrm{g} \mathrm{ml}^{-1}\right)$ analysed in the same 96 -well plate.

\section{Ammonia quantification}

Ammonia concentrations in serum were quantified using the indophenol assay method (Bolz \& Howel 1978). Defrosted serum was de-proteinised in an equal volume of $5 \%$ trichloro-acetic acid. After centrifugation, $100 \mu \mathrm{l}$ of supernatant were diluted 5 -fold in marine saline. To $100 \mu \mathrm{l}$ of diluted serum, we added $50 \mu \mathrm{l}$ of reagent $1(10 \mathrm{~g}$ phenol, $50 \mathrm{mg}$ sodium

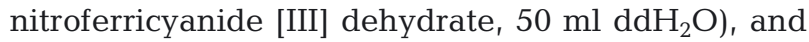
the sample was shaken for $30 \mathrm{~s}$. Reagent $2\left(50 \mu l_{\text {; }}\right.$

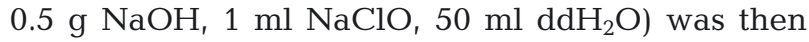
added and the plate incubated at $37^{\circ} \mathrm{C}$ for $30 \mathrm{~min}$ before being measured at $A_{635}$. The serum ammonia content was quantified relative to a dilution series of $\mathrm{NH}_{4} \mathrm{Cl}$ standards $\left(0-1 \mu \mathrm{g} \mathrm{ml}^{-1}\right)$ analysed in the same 96-well plate.

\section{Statistics}

Statistical analyses employed Microsoft Excel and GraphPad Prism 6.0 for Mac (OSX Version 10.9.1).
All data were first tested for a Gaussian distribution using a Kolmogorov-Smirnov test (K-S test). Spearman's rank correlation coefficient was then used to correlate parasite load (parasite count per lobster) against protein, haemocyanin, ammonia and glucose concentration, as well as lobster carapace length.

\section{RESULTS}

All 18 lobsters examined were found to be parasitized by Nicothoë astaci. Total numbers of parasites determined from gill photographs varied from 27 to 130 lobster $^{-1}(\mathrm{n}=18$, mean $\pm \mathrm{SD}=91 \pm 63$; male $\mathrm{n}=$ $3,55 \pm 19$; female $\mathrm{n}=15,98 \pm 67$; Table 1, Fig. 1) During the $28 \mathrm{~d}$ study, no lobsters moulted, but 2 females became berried and as their haemolymph protein levels increased during this time, they were excluded from the analyses (data not shown). As all other lobsters showed only minor changes in haemolymph total protein, haemocyanin, glucose or ammonia levels at each of the 4 wk sampling points (data not shown), only data obtained on Day 28 are reported here.

Haemolymph total protein levels correlated significantly with parasite load ( $\mathrm{p}=0.02$; Fig. 2A). Haemolymph haemocyanin levels also correlated significantly with parasite load, but only when 1 premoult lobster ( $\mathrm{R}$ in Table 1 ) with a high protein concentration throughout the $28 \mathrm{~d}$ study was omitted from the dataset ( $p=0.0065$; Fig. $2 B$ ). In contrast, no

Table 1. Summary of European lobsters Homarus gammarus sampled and levels of parasitization by the copepod Nicothoë astaci. F: female; M: male

\begin{tabular}{|c|c|c|c|c|c|c|c|}
\hline \multirow[t]{2}{*}{ Lobster } & \multirow[t]{2}{*}{ Sex } & \multirow{2}{*}{$\begin{array}{l}\text { Size } \\
(\mathrm{mm})\end{array}$} & \multirow{2}{*}{$\begin{array}{l}\text { Weight } \\
\text { (g) }\end{array}$} & \multicolumn{3}{|c|}{ Parasite number } & \multirow[t]{2}{*}{ Additional observations } \\
\hline & & & & Left gills & Right gills & Total & \\
\hline $\mathrm{A}$ & $\mathrm{F}$ & 100 & 622 & 51 & 56 & 107 & Epibiont (suspected monogenean) also found on gills \\
\hline $\mathrm{B}$ & $\mathrm{F}$ & 92 & 529 & 91 & 110 & 201 & Deformed carapace \\
\hline $\mathrm{C}$ & $\mathrm{F}$ & 94 & 577 & 16 & 20 & 36 & \\
\hline $\mathrm{D}$ & $\mathrm{F}$ & 97 & 581 & 12 & 15 & 27 & \\
\hline $\mathrm{E}$ & $\mathrm{F}$ & 92 & 489 & 62 & 45 & 107 & \\
\hline $\mathrm{F}$ & F & 98 & 689 & 48 & 28 & 76 & Became berried \\
\hline $\mathrm{G}$ & M & 99 & 648 & 30 & 25 & 55 & \\
\hline $\mathrm{H}$ & $\mathrm{F}$ & 92 & 531 & 135 & 95 & 230 & \\
\hline I & $\mathrm{F}$ & 91 & 470 & 20 & 18 & 38 & \\
\hline $\mathrm{J}$ & F & 95 & 573 & 14 & 17 & 31 & \\
\hline $\mathrm{K}$ & F & 95 & 530 & 17 & 30 & 47 & \\
\hline $\mathrm{L}$ & $\mathrm{F}$ & 94 & 602 & 83 & 104 & 187 & \\
\hline $\mathrm{M}$ & $\mathrm{F}$ & 97 & 581 & 74 & 65 & 139 & Became berried \\
\hline $\mathrm{N}$ & M & 105 & 776 & 14 & 22 & 36 & \\
\hline $\mathrm{O}$ & $\mathrm{F}$ & 96 & 536 & 75 & 54 & 129 & \\
\hline $\mathrm{P}$ & $\mathrm{F}$ & 97 & 566 & 26 & 41 & 67 & \\
\hline Q & $\mathrm{F}$ & 97 & 524 & 19 & 24 & 43 & Right chela missing \\
\hline $\mathrm{R}$ & M & 99 & 641 & 42 & 31 & 73 & Pre-moult upon dissection \\
\hline
\end{tabular}



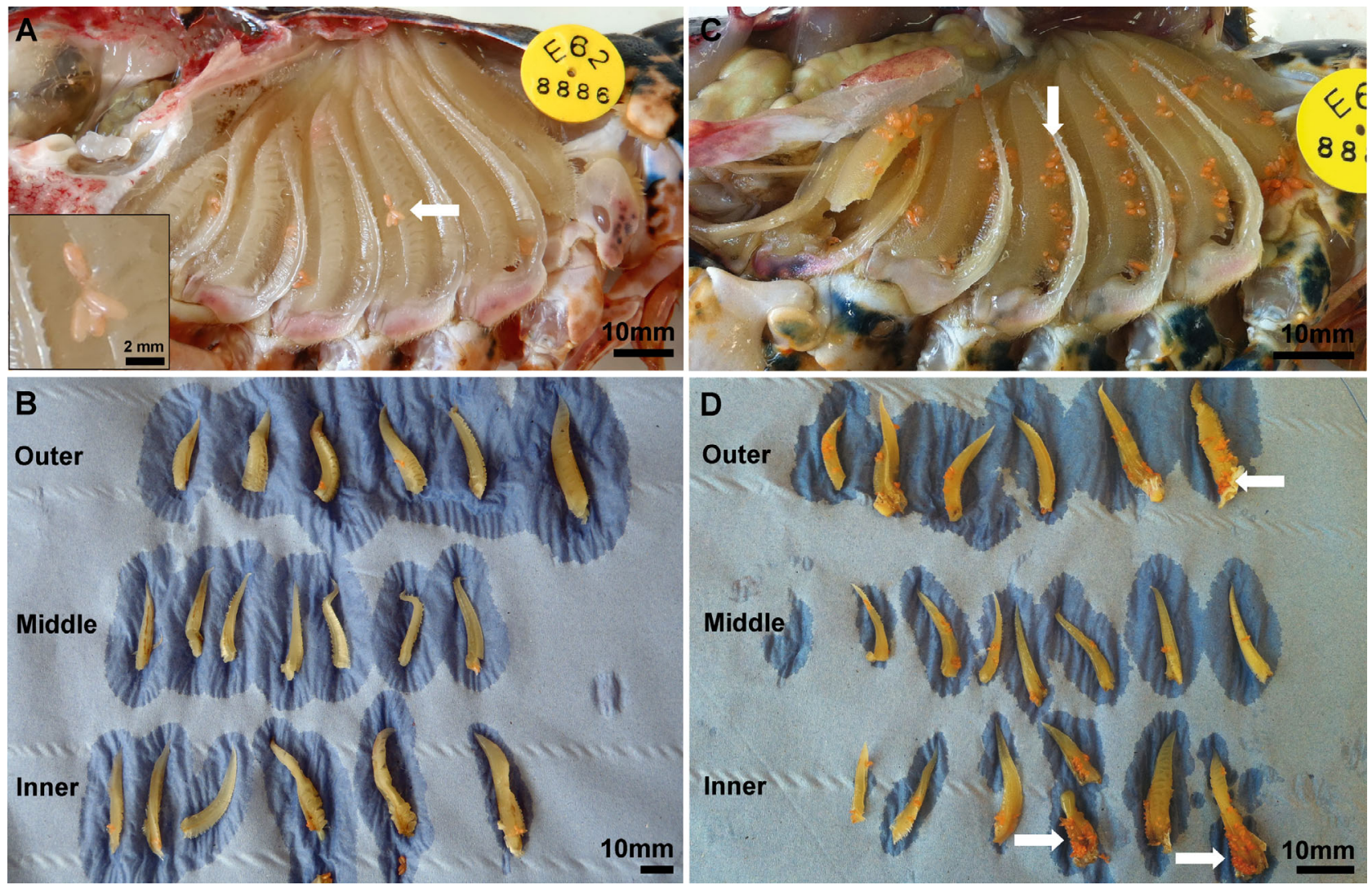

Fig. 1. Photographs showing examples of $(A, B)$ low and $(C, D)$ high levels of Nicothoë astaci (arrows) in the gills of European lobster Homarus gammarus before $(A, C)$ and after $(B, D)$ excision. Inset shows the structure of the parasites. Note the high numbers of parasites at the base of the gills in the lobster with high parasite load (arrows). The excised gills show the arrangement of gills into outer, middle and inner sets

correlations were apparent between gill parasite load and haemolymph glucose levels $(\mathrm{p}=0.2112$; Fig. 2C), ammonia levels ( $p=0.1290$; Fig. 2D) or lobster size $\left(\mathrm{p}=0.1269, \mathrm{R}^{2}=0.1699\right)$. Haemocyanin accounted for $84.2 \pm 19.1 \%($ mean $\pm S D, n=15)$ of the total haemolymph protein.

\section{DISCUSSION}

Higher loads of Nicothoë astaci copepods in the gills of Homarus gammarus lobsters were here associated with elevated haemolymph total protein and haemocyanin levels. As haemocyanin constitutes ca. $90 \%$ of total protein in crustacean haemolymph (Uglow 1969, Ghidalia 1985), increased haemocyanin levels appear the most likely contributor to elevated total protein levels. However, increases in other less abundant proteins cannot be discounted. Increased circulating haemocyanin levels may result in lobsters as a compensatory mechanism for reduced respiratory function due to parasite-induced gill damage as reported by Wootton et al. (2011). Indeed, hypoxia can trigger elevated haemocyanin levels in several crustacean species (Hagerman \& Pihl Baden 1988, Hagerman et al. 1990). Moreover, in other crustacean species such as the blue crab Callinectes sapidus, injection of the pathogenic bacterium Vibrio campbellii results in haemocytes aggregating in the gill lamellae, thus restricting haemolymph circulation and oxygen uptake through these narrow channels (Burnett et al. 2006). Hence the cellular defence response (aggregation of haemocytes) caused by parasites and pathogens may cause temporary or permanent damage to the capacity of gaseous exchange in the gills, which the lobster attempts to compensate for by producing increased amounts of haemocyanin.

Other members of the haemocyanin protein family include cryptocyanin and phenoloxidase (Terwilliger et al. 2006). While cryptocyanin does not bind oxygen like haemocyanin or phenoloxidase due to critical copper-binding histidine residues being reduced, levels of these proteins become elevated immediately prior to ecdysis before returning to nor- 

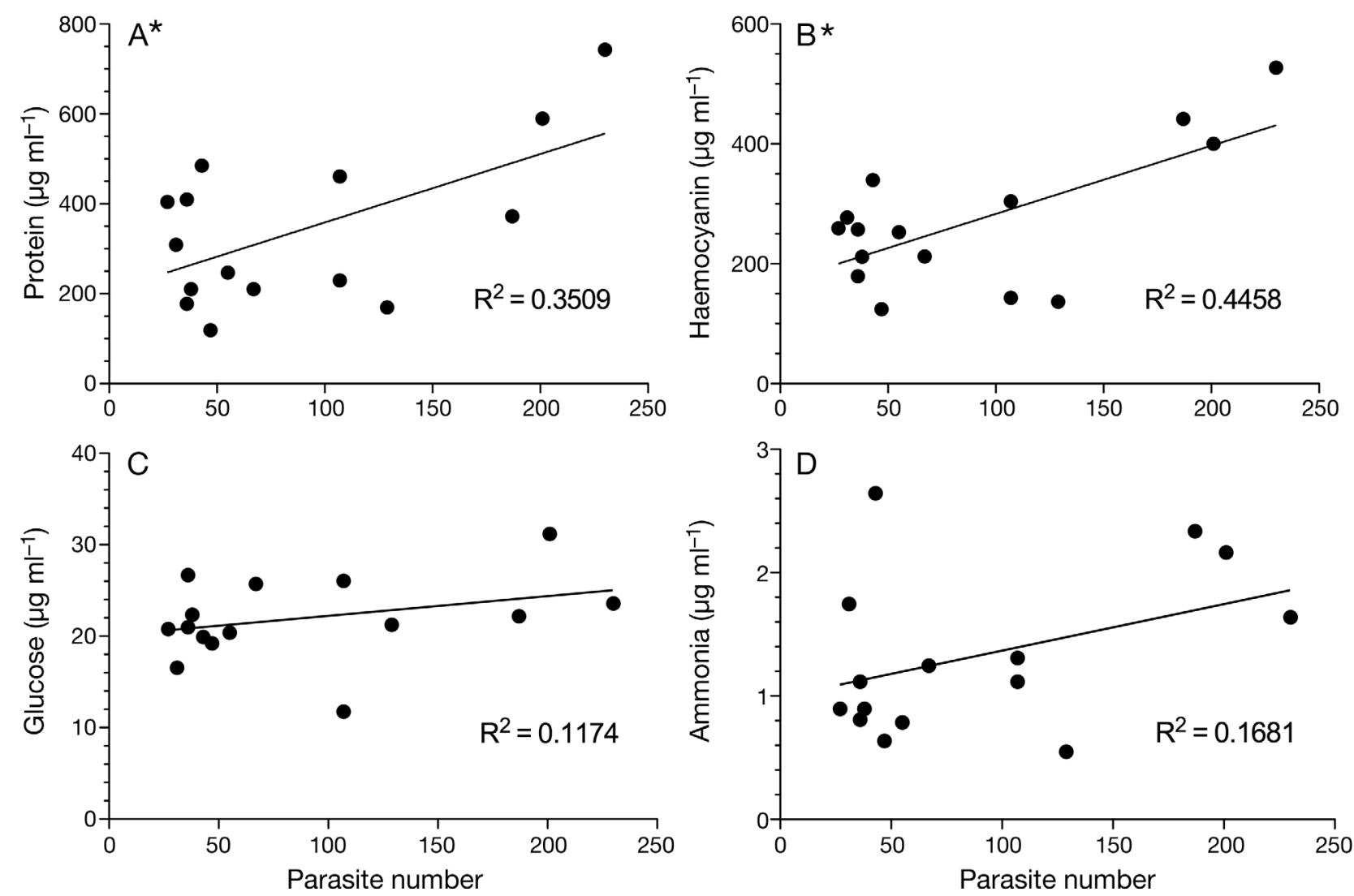

Fig. 2. Spearman's correlation coefficient analysis showing correlations between parasite Nicothoë astaci numbers and haemolymph concentrations of $(A)$ total protein $(p=0.02)$, (B) haemocyanin $(p=0.0065)$, (C) glucose $(p=0.2112)$ and (D) ammonia $(p=0.1290)$ in European lobster Homarus gammarus. Asterisks denote significance

mal post-moult (Terwilliger et al. 1999, 2006). One lobster examined here ( $\mathrm{R}$ in Table 1) was found to be pre-moult when dissected at the final sampling point. Since cryptocyanin and haemocyanin also have an absorbance peak at $A_{340}$, and both increase markedly in pre-moult crustaceans (Terwilliger et al. 1999, Kuballa et al. 2011), haemocyanin levels quantified for this individual might have been anomalous and were thus omitted from the dataset.

In invertebrates, the enzyme phenoloxidase catalyses melanin formation via the prophenoloxidase cascade (Cerenius et al. 2008). This cascade also results in the formation of key immune modulators; for example, gene knockout of this enzyme leaves shrimp immune deficient (Liu et al. 2007). In some crustaceans, haemocyanin cleavage results in the formation of an enzyme with catalytic activities similar to that of phenoloxidase (Adachi et al. 2003, Decker et al. 2007, Terwilliger 2007). In addition, some peptide fragments of haemocyanin have antifungal (Destoumieux-Garzón et al. 2001), antibacterial (Lee et al. 2003) and antiviral (Lei et al. 2008) activities. It is possible, therefore, that haemocyanin levels in lobsters parasitized by N. astaci might also become elevated as part of the defence response to this parasite.

No significant correlation was detected between $N$. astaci load and $H$. gammarus haemolymph glucose levels. However, stress or pathology resulting from disease infection has previously been associated with either increases (Telford 1968, SpindlerBarth 1976, Santos \& Keller 1993, Powell \& Rowley 2008) or decreases (Stentiford et al. 2001) in glucose levels. Parasites may absorb glucose from haemolymph, thereby forcing the host to resupply tissues with this sugar from glycogen reserves in the hepatopancreas in order to maintain carbohydrate homeostasis (Stentiford et al. 2001). It is possible that elevated glucose was not identified here due to $N$. astaci either being less invasive than other pathogens previously studied, or potentially not feeding constantly on haemolymph.

No significant correlation was detected between $N$. astaci load and $H$. gammarus haemolymph ammonia 
levels. Stressors including pathogens can lead to increased respiration in crustaceans, resulting in elevated ammonia excretion due to levels becoming elevated in haemolymph (Yoganandhan et al. 2003). However, since ammonia is excreted from gills (Taylor \& Taylor 1992), significant damage to this tissue may be expected to result in ammonium and other cellular metabolites becoming accumulated and therefore elevated in the haemolymph. Thus either the gill damage caused by $N$. astaci was not sufficient to impair ammonia excretion, or there is a switch in nitrogenous wastes to products such as urate or urea (Dykens 1991, Chen et al. 1994, Vogan \& Rowley 2002) which were not examined. Another explanation may be that since ammonia is a minor component of haemolymph, and as all lobsters examined were parasitized by $N$. astaci to some extent, any increase in levels was not able to be resolved as easily as other constituents assayed for.

In summary, increased loads of $N$. astaci on the gills of European lobsters were found to correlate with increased haemocyanin and thus total protein concentrations in haemolymph. This most likely compensates for reduced respiratory function due to gill damage reported previously (Wootton et al. 2011). Increased haemocyanin, which may be a generalized host response as well as compensatory, may well be advantageous for infected lobsters. It would now be of great interest to investigate a wider host immune response on a larger scale.

Acknowledgements. We thank skipper Geoff Huelin and crew of FV 'Our Jenny', and Michael François for assistance with sampling. We also thank Dr. Dan Forman (Department of Biosciences, Swansea University) for the use of his Pro Vision PV2-2in1 endoscope and Dr. Ed Dudley (College of Medicine, Swansea University) for advice on the spectrophotometric determination of haemocyanin. We also thank the 3 anonymous reviewers for their valuable comments on the manuscript. This study was partially supported by the Interreg IVA Ireland Wales project, SUSFISH, awarded to A.F.R. C.E.D. was partially supported by a tuition fee scholarship from the Colleges of Science and Medicine, Swansea University, and a bursary from the Educational Charity of John Mathews (RC 525553).

\section{LITERATURE CITED}

Adachi K, Hirata T, Nishioka T, Sakaguchi M (2003) Hemocyte components in crustaceans convert hemocyanin into a phenoloxidase-like enzyme. Comp Biochem Physiol B 134:135-141

Antonini E, Brunori M (1974) Transport of oxygen; respiratory proteins. In: Hayaishi $\mathrm{O}$ (ed) Molecular oxygen in biology: topics in molecular oxygen research. NorthHolland Pub Co, Amsterdam, p 219-274
Battison A, MacMillan R, MacKenzie A, Rose P, Cawthorn R, Horney B (2000) Use of injectable potassium chloride for euthanasia of American lobsters (Homarus americanus). Comp Med 50:545-550

Bolz DF, Howel JA (1978) Colorimetric determination of non-metals. Wiley, London

Brouwer M, Larkin P, Brown-Peterson N, King C, Manning S, Denslow N (2004) Effects of hypoxia on gene and protein expression in the blue crab, Callinectes sapidus. Mar Environ Res 58:787-792

Burnett LE (1992) Integrated function of the respiratory pigment hemocyanin in crabs. Am Zool 32:438-446

Burnett LE, Holman JD, Jorgensen DD, Ikerd JL, Burnett KG (2006) Immune defense reduces respiratory fitness in Callinectes sapidus, the Atlantic blue crab. Biol Bull (Woods Hole) 211:50-57

Cerenius L, Lee BL, Söderhäll K (2008) The proPO-system: pros and cons for its role in invertebrate immunity. Trends Immunol 29:263-271

Chang ES (2005) Stressed-out lobsters: crustacean hyperglycemic hormone and stress proteins. Integr Comp Biol 45:43-50

> Chen JC, Chen CT, Cheng SY (1994) Nitrogen excretion and changes of hemocyanin, protein and free amino acid levels in the hemolymph of Penaeus monodon exposed to different concentrations of ambient ammonia-N at different salinity levels. Mar Ecol Prog Ser 110:85-95

Claybrook DL (1983) Nitrogen metabolism. In: Bliss DE, Mantel LH (eds) The biology of Crustacea, Vol 5. Internal anatomy and physiological regulation. Academic Press, London, p 189-193

Davies CE, Thomas GR, Maffeis TGG, Wootton EC, Penny MW, Rowley AF (2014) Detailed surface morphology of the 'lobster louse' copepod, Nicothoë astaci, a haematophagous gill parasite of the European lobster, Homarus gammarus. J Invertebr Pathol 122:48-51

> Decker H, Hellmann N, Jaenicke E, Lieb B, Meissner U, Markl J (2007) Minireview: recent progress in hemocyanin research. Integr Comp Biol 47:631-644

> Depledge MH, Bjerregaard P (1989) Haemolymph protein composition and copper levels in decapod crustaceans. Helgol Meeresunters 43:207-223

> Destoumieux-Garzón D, Saulnier D, Garnier J, Jouffrey C, Bulet P, Bachère E (2001) Crustacean immunity: antifungal peptides are generated from the $\mathrm{C}$ terminus of shrimp hemocyanin in response to microbial challenge. J Biol Chem 276:47070-47077

Dykens JA (1991) Purineolytic capacity and origin of hemolymph urate in Carcinus maenas during hypoxia. Comp Biochem Physiol B 98:579-582

Ghidalia W (1985) Structural and biological aspects of pigments. In: Bliss DE, Mantel LH (eds) The biology of Crustacea, Vol 9. Integument, pigments and hormonal processes. Academic Press, London, p 321-340

> Hagerman L (1983) Haemocyanin concentration of juvenile lobsters (Homarus gammarus) in relation to moulting cycle and feeding conditions. Mar Biol 77:11-17

> Hagerman L, Pihl Baden S (1988) Nephrops norvegicus: field study of effects of oxygen deficiency on haemocyanin concentration. J Exp Mar Biol Ecol 116: 135-142

Hagerman L, Sondergaard T, Hosie D, Uglow RF (1990) Aspects of blood physiology and ammonia excretion in Nephrops norvegicus under hypoxia. Comp Biochem Physiol A 97:51-55 
Hsia CC, Schmitz A, Lambertz M, Perry SF, Maina JN (2013) Evolution of air breathing: oxygen homeostasis and the transitions from water to land and sky. Compr Physiol 3: 849-915

Hunter DA, Uglow RF (1993) Handling-induced changes in haemolymph ammonia concentration and ammonia excretion rate of Crangon crangon (L.). Ophelia 38: 137-147

Jones TR (1861) Nicothoë astaci. In: Van Voorst J (ed) General outline of the organization of the animal kingdom, and manual of comparative anatomy. Taylor \& Francis, London, p 427-430

Kuballa AV, Holton TA, Paterson B, Elizur A (2011) Moult cycle specific differential gene expression profiling in the crab Portunus pelagius. BMC Genomics 12:147

Lee SY, Lee BL, Söderhäll K (2003) Processing of an antibacterial peptide from hemocyanin of the freshwater crayfish Pacifastacus leniusculus. J Biol Chem 278:7927-7933

Lei K, Li F, Zhang M, Yang HJ, Luo T, Xu X (2008) Difference between hemocyanian subunits from shrimp Penaeus japonicus in anti-WSSV defense. Dev Comp Immunol 32:808-813

Liu H, Jiravanichpaisal P, Cerenius L, Lee BL, Söderhäll I, Söderhäll K (2007) Phenoloxidase is an important component of the defense against Aeromonas hydrophila infection in a crustacean, Pacifastacus leniusculus. J Biol Chem 282:33593-33598

Mason J (1959) The biology of Nicothoë astaci Audouin and Milne Edwards. J Mar Biol Assoc UK 38:3-16

Monteiro L (2008) Parasites as cause of rejection in Portuguese fish markets. In: Afonso-Dias I, Menezes G, Mackenzie K, Eiras JC (eds) Applied aspects of marine parasitology. Proceedings of the International Workshop on Marine Parasitology, Horta, 21-24 May 2006. Arquipélago-Life Mar Sci Suppl 6:45-46

Nickerson KW, Van Holde KE (1971) A comparison of molluscan and arthropod hemocyanin - I. Circular dichroism and absorption spectra. Comp Biochem Physiol B 39: 855-872

> Powell A, Rowley AF (2008) Tissue changes in the shore crab Carcinus maenas as a result of infection by the parasitic barnacle Sacculina carcini. Dis Aquat Org 80: 75-79

Regnault M (1987) Nitrogen excretion in marine and freshwater Crustacea. Biol Rev Camb Philos Soc 62:1-24

Santos EA, Keller R (1993) Effect of exposure to atmospheric air on blood glucose and lactate concentrations in two crustacean species: a role for crustacean hyperglycaemic hormone (CHH). Comp Biochem Physiol A 106:343-347

Spindler-Barth M (1976) A bacterial infection in the common shore crab Carcinus maenas and the fiddler crab UCa pugilator. Mar Biol 36:1-4

Stentiford GD, Chang ES, Chang SA, Neil DM (2001) Carbo-

Editorial responsibility: Jeff Cowley,

Brisbane, Queensland, Australia hydrate dynamics and the crustacean hyperglycemic hormone $(\mathrm{CHH})$ : effects of parasitic infection in Norway lobsters (Nephrops norvegicus). Gen Comp Endocrinol 121:13-22

Stewart JE, Li MF (1969) A study of lobster (Homarus americanus) ecology using serum protein concentration as an index. Can J Zool 47:21-28

- Stewart JE, Cornick JW, Foley DM, Li MF, Bishop CM (1967) Muscle weight relationship to serum proteins, hemocytes, and hepatopancreas in the lobster, Homarus americanus. J Fish Res Board Can 24:2339-2354

Taylor HH, Taylor EW (1992) Gills and lungs: the exchange of gases and ions. In: Harrison FW, Humes AG (eds) Microscopic anatomy of invertebrates, Vol 10. WileyLiss, New York, NY, p 203-293

Taylor EW, Whiteley NM (1989) Oxygen transport and acid-base balance in the hemolymph of the lobster Homarus gammarus during aerial exposure and resubmersion. J Exp Biol 144:417-436

Telford M (1968) The effects of stress on blood sugar composition of the lobster, Homarus americanus. Can J Zool 46: 819-826

$>$ Terwilliger NB (2007) Hemocyanins and the immune response: defense against the dark arts. Integr Comp Biol 47:662-665

Terwilliger NB, Dangott L, Ryan M (1999) Cryptocyanin, a crustacean molting protein: evolutionary link with arthropod hemocyanins and insect hexamerins. Proc Natl Acad Sci USA 96:2013-2018

Terwilliger NB, Ryan M, Phillips MR (2006) Crustacean hemocyanin gene family and microarray studies of expression change during eco-physiological stress. Integr Comp Biol 46:991-999

Truchot JP (1983) Regulation of acid-base balance. In: Bliss DE, Mantel LH (eds) The biology of Crustacea, Vol 5. Internal anatomy and physiological regulation. Academic Press, London, p 437-446

> Uglow RF (1969) Hemolymph protein concentrations in portunid crabs - I. Studies on adult Carcinus maenas. Comp Biochem Physiol 30:1083-1090

- Vogan CL, Rowley AF (2002) Dynamics of shell disease in the edible crab Cancer pagurus: a comparative study between two sites on the Gower Peninsula, South Wales, UK. Dis Aquat Org 52:151-157

> Wootton EC, Pope EC, Vogan CL, Roberts EC, Davies CE, Rowley AF (2011) Morphology and pathology of the ectoparasitic copepod, Nicothoë astaci ('lobster louse') in the European lobster, Homarus gammarus. Parasitology 138: 1285-1295

- Yoganandhan K, Thirupathi S, Sahul Hameed AS (2003) Biochemical, physiological and hematological changes in white spot syndrome virus-infected shrimp, Penaeus indicus. Aquaculture 221:1-11

Submitted: July 28, 2014; Accepted: October 8, 2014

Proofs received from author(s): February 1, 2015 